\title{
ERADICATION OF VIRUSES IN MICROPLANTS OF THREE CULTIVATED POTATO SPECIES (Solanum tuberosum L., S. phureja Juz. \& Buk., S. stenotomum Juz. \& Buk.) USING COMBINED THERMO-CHEMOTHERAPY METHOD
}

\section{O.Yu. ANTONOVA, O.V. APALIKOVA, Yu.V. UKHATOVA, E.A. KRYLOVA, O.Yu. SHUVALOV, A.R. SHUVALOVA, T.A. GAVRILENKO}

\begin{abstract}
Federal Research Center the N.I. Vavilov All-Russian Institute of Plant Genetic Resources, Federal Agency of Scientific Organizations, 42-44, ul. Bol'shaya Morskaya, St. Petersburg, 190000 Russia, e-mail tatjana9972@yandex.ru ORCID:

Antonova O.Yu. orcid.org/0000-0001-8334-8069 Apalikova O.V. orcid.org/0000-0002-1188-2446

The authors declare no conflict of interests Acknowledgements:

The paper was prepared with the support from the Basic Research Program performed at state academies for 20132020. The final stage of the work was partially supported by the Special Complex Program of the Russian Federation (2016-2025) on improving the competitiveness of agricultural products (priority for potato research) Received October 17, 2016

Ukhatova Yu.V. orcid.org/0000-0001-9366-0216 Gavrilenko T.A. orcid.org/0000-0002-2605-6569
\end{abstract}

\section{Abstract}

A modified method of combined chemo-thermotherapy for eradication the most damaging viruses in potato plants is proposed. The materials for study included 91 clones of 85 accessions of three South-American cultivated species Solanum phureja (18 accessions), S. stenotomum (26 accessions), S. tuberosum ( $S$. tuberosum ssp. andigenum and $S$. tuberosum ssp. tuberosum) (41 accessions) from the VIR field collection (N.I. Vavilov All-Russian Institute of Plant Genetic Resources). The results of ELISA for 91 clones from the field collection and RT-PCR analysis of the corresponding microplants, when introducing clones into in vitro culture, have shown that all material was infected by viruses (potato viruses $\mathrm{Y}, \mathrm{X}, \mathrm{S}, \mathrm{M}$ and potato leafroll virus - PVY, PVX, PVS, PVM and PLRV) to varying degrees. Single infections were detected in $25.3 \%$ of the 91 clones, and the remaining clones were multi-infected and contained several viruses in various combinations. Based on the termo- and chemotherapy protocols as well as complex therapy used in leading potato genebanks (Leibniz Institute of Plant Genetics and Crop Plant Research - IPK, Germany; International Potato Centre - CIP, Peru), we have developed a modified method of combined therapy comprising three successive cycles of in vitro plant cultivation on Murashige and Skoog basal medium (MS) supplemented with ribavirin $(30 \mathrm{mg} / \mathrm{l})$ at $37{ }^{\circ} \mathrm{C}$ during 4 weeks. Between the cycles, the microplants were incubated for 2 days at $26{ }^{\circ} \mathrm{C}$ on the same medium with ribavirin. Each clone was tested for the presence of viruses by RT (revers transcription) PCR before and after the combined thermo-chemotherapy. In RT-PCR, 42 clones $(46 \%)$ were completely free from tested viruses, $44 \%$ were free from some viruses, and $10 \%$ of the clones were unable to improve. On the whole of 91 clones, PLRV was eliminated from $72.7 \%$, PVY from $71.4 \%$, PVM from $63.9 \%$ and PVS from $57.4 \%$ of microplants. Differences in elimination frequency between the viruses were not significant $(\mathrm{p}>0.05)$. Also, there were no significant differences in elimination of different viruses between the accessions of different cultivated species. The difference of this modification from IPK protocols (Germany) lays in simultaneous effect of high temperature $\left(37^{\circ} \mathrm{C}\right)$ and ribavirin (instead of sequential application), and, unlike the CIP (Peru) scheme, it comprises less steps.

Keywords: potatoes, Solanum tuberosum, Solanum phureja, Solanum stenotomum, microplants, PVY, PVX, PVS, PVM, PLRV, virus eradication, RT-PCR, thermotherapy, chemotherapy

Potato VIR Collection (N.I. Vavilov All-Russian Institute of Plant Genetic Resources) of about 8,500 samples of breeding varieties, wild and cultivated species, as well as interspecific hybrids [1] is one of the largest and oldest in the world. Samples of potatoes of field collections, long reproduced by tubers, can accumulate viral infections. There are about 40 viruses infecting potatoes, the most destructive are potato virus Y (PVY), potato leafroll virus (PLRV), po- 
tato virus $\mathrm{M}$ (PVM), potato virus $\mathrm{S}$ (PVS), potato virus X (PVX), potato virus $\mathrm{A}$ (PVA) [2-4)]. On the territory of Russia and the CIS countries, PVY, PLRV, PVM, PVS, PVX are the most frequent, and potato virus F and PVA are less detectable [5]. Under field conditions, viruses are transmitted mainly by insect vectors (mostly aphids), as well as via contacts [3].

For virus eradication from plants one can use apical meristem cultures, chemo-, thermo-, cryo- and electrotherapy, and their various combinations (complex/combined therapy). Apical meristems, which was one of the first developed $[6,7]$, is relatively low-cost and is still widely used. However, for large collections, numbering thousands of samples, it becomes less popular due to laboriousness and because of development of more effective combined approaches. During the cryotherapy in liquid nitrogen $\left(-196{ }^{\circ} \mathrm{C}\right)$ only meristem cells potentially free from viruses remain viable, and hydrated cells outside the meristem zone die [8]. The method of electrotherapy is based on plant tissues exposure to electrical current, resulting in the degradation of the viral nucleoprotein and the loss of virulence $[9,10]$.

Thermotherapy in vivo and in vitro is based on a decrease in the titer of viruses in infected plant tissues due to disruption in the synthesis of viral RNA at elevated temperatures $\left(36-40{ }^{\circ} \mathrm{C}\right)$ [12]. The method is less effective against spherical viruses [4], so when mixed infections it is recommended to combine said technique with other ones. Chemotherapy is based on the treatment of infected plants with substances with antiviral activity. These include inhibitors of the synthesis of viral nucleic acids such as tylophorin and its derivatives, the analogues of purine and pyrimidine bases including ribavirin, etc. [11-13], as well as RNase [14], interferon [15], growth stimulants [16] and phenolic compounds, in particular salicylic acid [17]. Ribavirin, a synthetic analogue of guanosine (1-beta-D-ribofuranosyl-1H-1,2,4-triazole-3-carboxamide), is most commonly used for in vitro chemotherapy in potato plants, but it should be remembered that low doses of the drug are ineffective [11], while at high dose it inhibits plant development [8]. The concentrations of 30-50 mg/l [11-13] are considered optimal.

In large centers of plant genetic resources, such as the International Potato Center (CIP, Peru) and the Leibniz Institute of Plant Genetics and Crop Plant Research (IPK, Germany), for the sanitation of collection potato samples, thermo- and chemotherapy schemes different in the number and duration of the stages are used, as well as therapy which provides different combinations of these methods [18-21]. The frequency of virus elimination can be additionally increased by using the culture of the apical meristem together with various combined therapy methods, including thermotherapy [22, 23], chemotherapy [25, 26], and thermo-chemotherapy [12, 26, 27].

It should be noted that antiviral therapy methods are not the same in efficiency, and in some cases the same approaches in different laboratories give contradictory results. Besides, most studies are performed on single varieties or a limited number of them, so it is not known how the proposed methods are applicable to large collections. Thus, the development of methods to restore potato plants from viral infections remains extremely urgent.

Taking as a basis the protocols of thermo- and chemotherapy, as well as the complex therapy of the leading potato genebanks (CIP and IPK), we modified the recovery schemes for large samples of genetically dissimilar potato samples with mixed viral infections in various combinations. Our modification differed from the IPK protocols due to simultaneous rather than a sequential application of elevated temperature $\left(37^{\circ} \mathrm{C}\right)$ and ribavirin, and from the CIP protocols due to a smaller number of stages [21]. 
The goal of the work is to compare known protocols, and to develop and verify a complex antiviral chemo-thermotherapy scheme for potato plant health sanitation in vitro.

Techniques. We used 91 plants of 85 samples of three South American cultivated potato species (indigenous varieties) - Solanum phureja (18 samples), S. stenotomum (26 samples), S. tuberosum ssp. andigenum (= S. andigenum) (23 samples), $S$. tuberosum ssp. tuberosum (= S. tuberosum) (18 samples) from VIR collection. The paper provides the names of the species according to the taxonomy system J. Hawkes (1990) [28] which is currently used most widely; the notation accepted in the VIR collection structured according to S.M. Bukasov (1978) [29] is given in brackets,. The studied samples which represent the expeditionary collections of different years were subsequently reproduced for a long time in the field collection.

The field grown plants were analyzed for the presence of PVM, PVY, PVS, PLRV and PVX by ELISA test using the kits and protocol of Agdia, Inc (USA) (https://orders.agdia.com) (data not provided) to selected clones among the plants of the field collection. To preserve the viral infection, in vitro tissue cultures were derived using apexes large in size $(2-4 \mathrm{~mm})$ [30]. The resulting micro-plants were maintained as a clone collection.

Total RNA preparations (including RNA viruses) were extrated from the lower leaves of test tube plants as described [31] using a commercial set for isolation on magnetic particles coated with $\mathrm{SiO}_{2}$ (Silex, Russia). The preparations were stored at $-70^{\circ} \mathrm{C}$. The reverse transcription was carried out using a Synthesis of the first cDNA strand (random) kit (Silex, Russia) in accordance with the attached protocol [32]. The kit includes a mixture of random hexanucleotide primers allowing simultaneous preparation of cDNA for all viral RNAs and for RNA of the tubulin gene as a control of successful matrix synthesis. Specific primers were synthesized in the Evrogen company (Russia), and amplification protocols for PVY, PVM, PVX, PVS and PLRV detection in PCR were as described [33-36). The efficiency of the template in PCR was monitored with primers specific for the tubulin protein gene [36]. The samples without RNA were the negative control. PCR was performed on a Mastercycler nexus gradient thermocycler (Eppendorf, Germany). To increase the specificity of PCR, the used programs included a TOUCHDOWN function: initially, the annealing temperature of the primers was set to $5^{\circ} \mathrm{C}$ above the required temperature and then decreased by $1{ }^{\circ} \mathrm{C}$ in each of the five amplification cycles. PCR products were separated by electrophoresis in $2.5 \%$ agarose gels, stained with ethidium bromide and visualized in UV light.

Prior to eradication, each clone was RT-PCR tested for viruses. The micro-plant sanitation was carried out by a combined thermo-chemotherapy that we modified. The Murashige-Skoog (MS) growth medium without hormones [30] was used, containing the antiviral drug ribavirin $(30 \mathrm{mg} / \mathrm{l})$. Combination therapy included three stages lasting 4 weeks each, in which the plants were affected by ribavirin at elevated temperatures $\left(37^{\circ} \mathrm{C}\right)$, and then kept on ribavirincontaining medium at $26^{\circ} \mathrm{C}$ for 1 month.

Statistical processing was carried out using Student's $t$-test at a significance level of $\mathrm{p} \leq 0.05$.

Results. Based on analysis of the known methods of virus eradication (Table 1), we proposed a modified protocol of antiviral therapy in vitro (Fig. 1) with the use of RT-PCR to detect infection. The effectiveness of this scheme for the most common viral potato pathogens was monitored in several species representatives of Solanum, using the primers specific for different genomic regions of the 
corresponding viruses (Table 2).

1. The effectiveness of various sanitation methods for potato cultural plants from viral infections

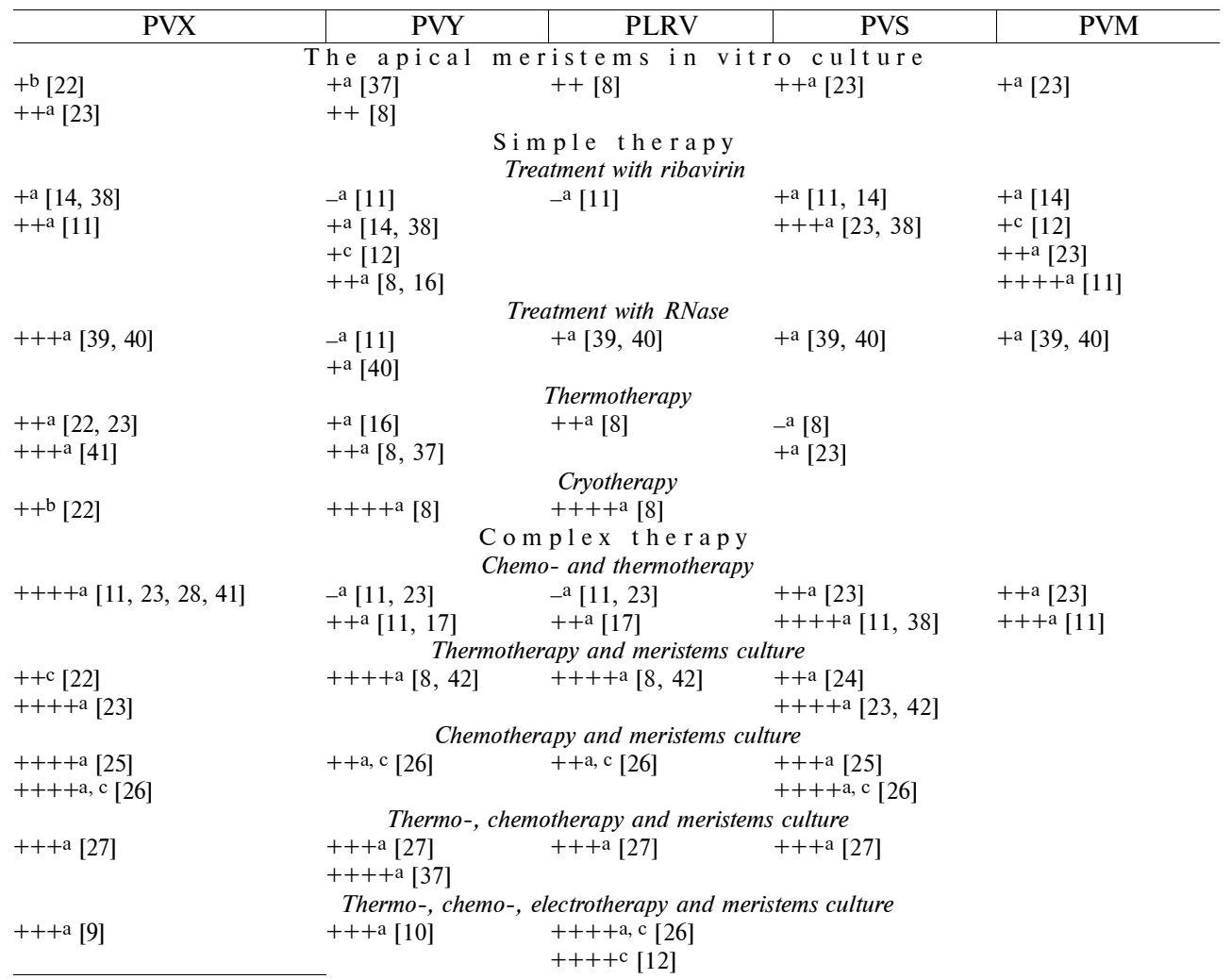

N o t e. PVX, PVY, PVS, PVM, PLRV - potato viruses X, Y, S, M, and potato leafroll virus; "_" - lack of effect; "+" - up to $40 \%$ of virus-free plants, "++" -41 to $60 \%$ of virus-free plants, "+++" -61 to $89 \%$ of virusfree plants, "++++" -90 to $98 \%$ of virus-free plants. The cited references are provided in brackets. Testing by enzyme multiplied immunoassay $\left({ }^{a}\right)$, in PCR with reverse transcription $\left({ }^{b}\right)$, using plant indicators or electron microscopy ${ }^{(c)}$. Gaps mean the absence of data.

1. RT-PCR test of micro-plants for the determination of viruses

2. Micropropagation of infected plants in vitro

3. Complex chemo- and thermotherapy:

3.1. grafting of micro-plants: for each genotype, 10-20 leafless cuttings (1-21 interstices) are planted on $\mathrm{Mu}-$ rashige-Skoog (MS) medium without hormones, kept at $26{ }^{\circ} \mathrm{C}$ for 1 day and then cultured at $37{ }^{\circ} \mathrm{C}$ for 4 weeks

3.2. obtaining leafless cuttings from plants that passed stage 3.1: micro-plants are cultured on MS medium with the addition of ribavirin $(30 \mathrm{mg} / \mathrm{l})$ at $20^{\circ} \mathrm{C}$ for $2-3$ days, then at $37^{\circ} \mathrm{C}$ for 4 weeks

3.3. obtaining leafless cuttings from plants that passed the stage 3.2: micro-plants are cultured on MS medium with the addition of ribavirin $(30 \mathrm{mg} / \mathrm{l})$ at $20^{\circ} \mathrm{C}$ for $2-3$ days, then at $37^{\circ} \mathrm{C}$ for 4 weeks

3.4. obtaining leafless cuttings from plants that passed step 3.3: the cuttings are kept at $26{ }^{\circ} \mathrm{C}$ for 1 day, then the micro-plants are cultured on MS medium with the addition of ribavirin $(30 \mathrm{mg} / \mathrm{l})$ at $20{ }^{\circ} \mathrm{C}$ for 4 weeks

3.5. transfer of micro-plants to MS medium without hormones, culture at $20^{\circ} \mathrm{C}$ for 2 months

4. Isolation of RNA and RT-PCR test of micro-plants for the determination of viruses

5. Micropropagation of healthy plants

Fig. 1. Modified regime for the recovery of micro-plants of cultivated potato species from viral infections based on complex thermo-chemotherapy. RT-PCR - PCR with reversed transcription.

\section{Primers used in the test for viruses determination}

\begin{tabular}{lll|c|c}
\hline \multicolumn{1}{c}{ Amplified RNA } & \multicolumn{1}{|l|}{ Pair of primers } & \multicolumn{1}{c|}{ Sequence } & $\mathrm{T},{ }^{\circ} \mathrm{C}$ & Reference \\
\hline Potato virus X & PVX1-f & AGGCCACAGGGTCGACTAC & 57 & {$[33]$} \\
& PVX1-r & TTGTTGTTCCAGTGATACGACC & & \\
Potato virus Y & PVY1-f & ACGTCCAAAATGAGAATGCC & 53 & {$[33]$} \\
& PVY1-r & TGGTGTTCGTGATGTGACCT & & \\
Potato leafroll virus & PLRV1-f & CGCGCTAACAGAGTTCAGCC & 58 & {$[33]$} \\
& PLRV1-r & GCAATGGGGGTCCAACTCAT & &
\end{tabular}




\begin{tabular}{llllc} 
& & & Table 2 (continued) \\
Potato virus S & PVS-f & TGGCGAACACCGAGCAAATG & 57 & [35] \\
& PVS-r & ATGATCGAGTCCAAGGGCACT & & [34] \\
Potato virus M & PVM4 & ACATCTGAGGACATGATGCGC & 59 & \\
& PVM3 & TGAGCTCGGGACCATTCAAC & & [36] \\
Control of reverse & tubul-f & ATGTTCAGGCGCAAGGCTT & 54 & \\
transcription (RT) & tubul-r & TCTGCAACCGGGTCATTCAT & & \\
\hline
\end{tabular}

A $\quad$ B
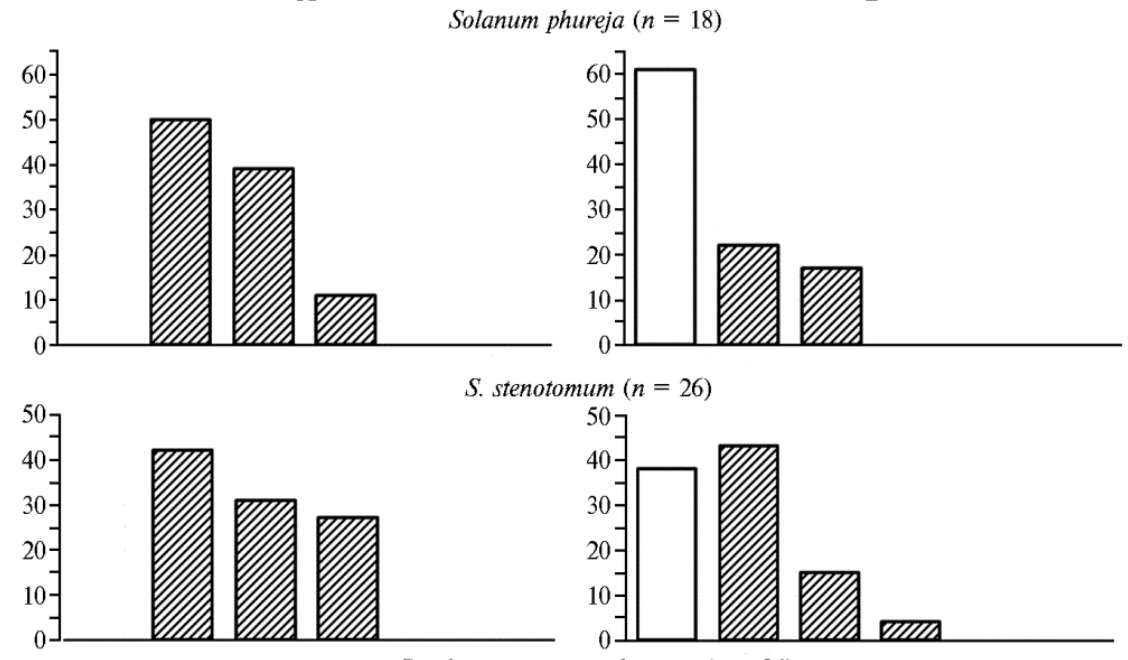

S. tuberosum ssp. andigenum $(n=24)$
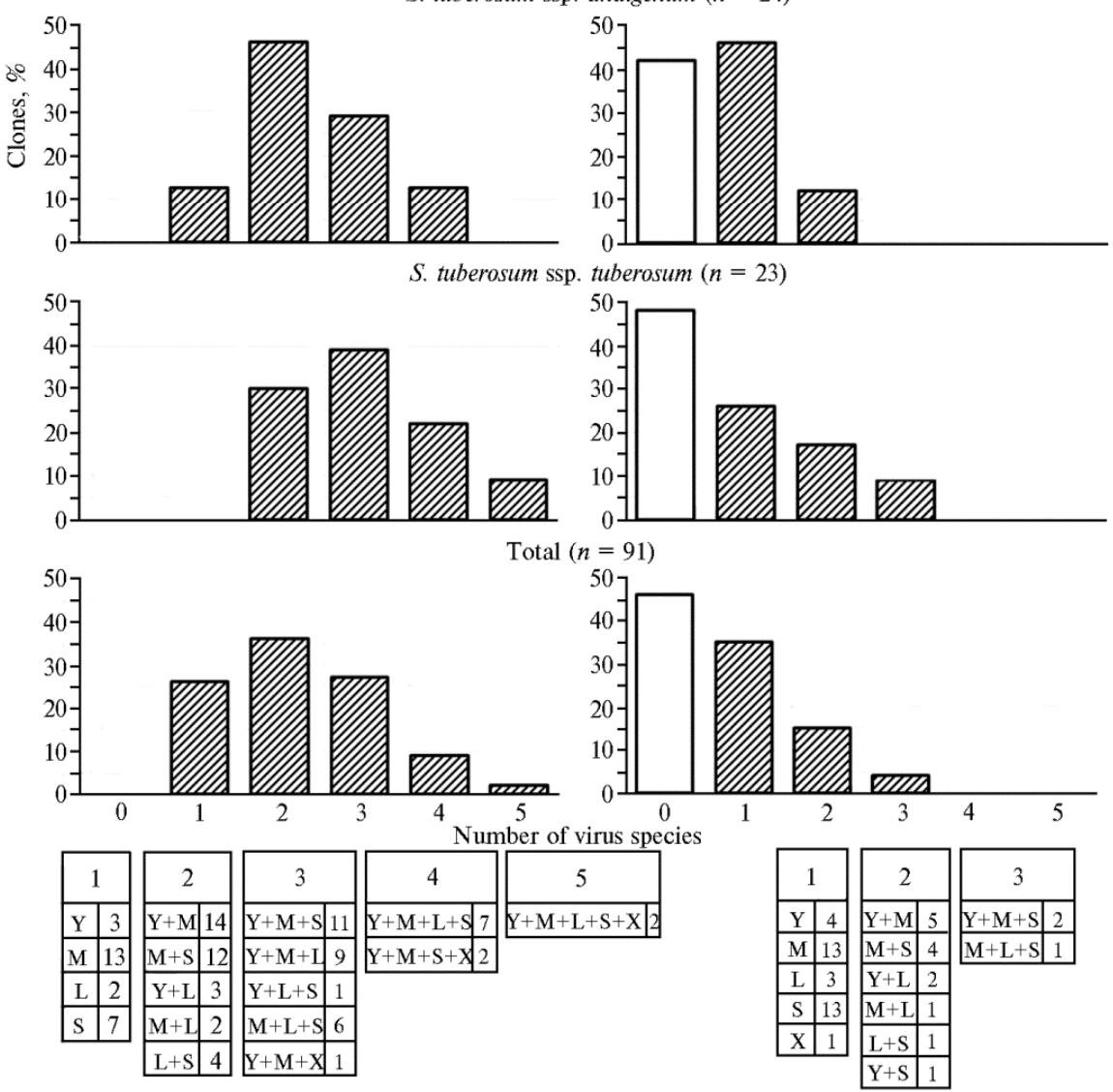

Fig. 2. The percentage of clones $(\%)$ among samples of cultivated potato species with various viral infections before (A) and after (B) application of the proposed complex thermo-chemotherapy in vitro protocol: $\mathrm{Y}, \mathrm{X}, \mathrm{S}, \mathrm{M}$ are potato virus $\mathrm{Y}, \mathrm{X}, \mathrm{S}$, and $\mathrm{M}$, respectively, and $\mathrm{L}$ is potato leafroll virus. 
As it was shown by ELISA for the original plants from the field collection (data not provided) and RT-PCR analysis of derived micro-plants of the same clones, all the samples were affected by viruses to different extents (Fig. 2, A). Simple infections were detected in $25.3 \%$ of the plants, however, the majority of selected clones had mixed infections of several viruses in different combinations, with the maximum number (five virus species) found in $S$. tuberosum ssp. tuberosum (see Fig. 2, A).

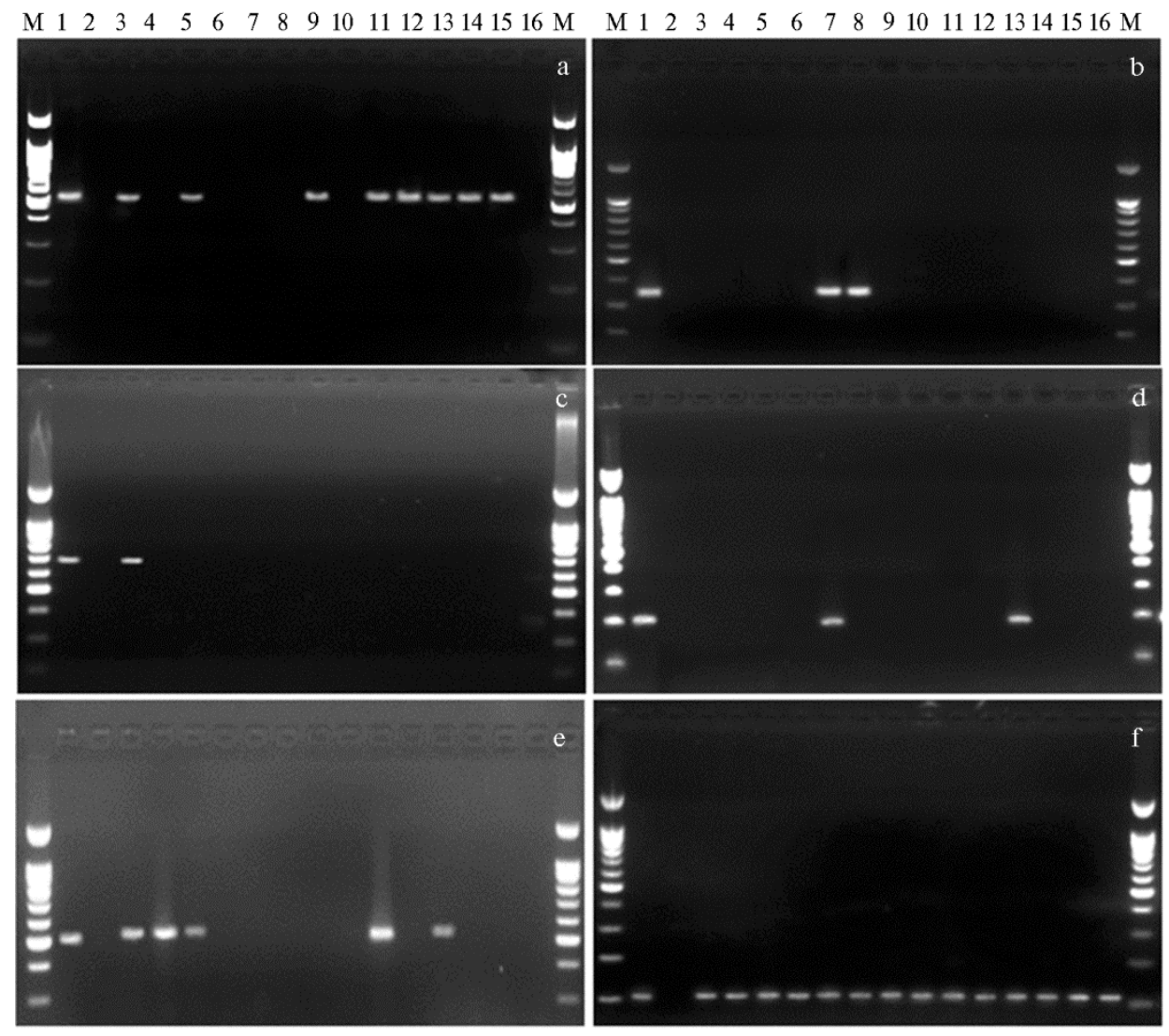

Fig. 3. Example of RT-PCR test of micro-plants of cultivated potato species for potato virus $Y$ (a), potato leaf roll viros (b), potato virus $X(c)$, potato virus $S(d)$, potato virus $M(e)$ when applying the proposed protocol of complex thermo-chemotherapy with the efficiency control of synthesis of the cDNA (f) matrix: 1 - field plant of Solanum tuberosum ssp. tuberosum clone (number in VIR collection k3414), which according to the results of ELISA is affected by all five viruses (positive control), $2-$ water (negative control); 3 and $4-S$. tuberosum ssp. andigenum clone (k-3172), 5 and $6-S$. tuberosum ssp. andigenum clone (k-3240), 7 and $8-S$. tuberosum ssp. andigenum clone (k-17961), 9 and $10-S$. phureja clone (k-12789), 11 and $12-S$. phureja clone (k-5642), 13 and $14-S$. stenotomum clone (k-8929), 15 and $16-S$. phureja clone (k-9835) (pairwise comparisons of the RTPCR results before and after treatment); $\mathrm{M}$ is a Molecular weight marker $100 \mathrm{bp}+1500$ (SibEnzim, Russia). RT-PCR - PCR with reverse transcription. VIR - N.I. Vavilov All-Russian Institute of Plant Genetic Resources.

Combined therapy significantly reduced viral damage of micro-plants (see Fig. 2, B, Fig. 3). Based on the results of RT-PCR analysis, 42 clones (46\%) of these underwent the recovery procedure were completely free from the tested viruses, in $44 \%$ of the clones some virus species were eliminated, and $10 \%$ of the clones failed to recover. Sixteen clones $(69.6 \%)$ with a simple infection and 26 clones $(38.2 \%)$ with mixed infections were fully revitalized. In other cases after the use of combined therapy, the number of clones with a multiple viral infection decreased. Thus, clones with four to five viral species were not detected, 
and the number of micro-plants with two viral species decreased significantly (see Fig. 2, B). These results are consistent with other data [16, 27] obtained in the comparative study of the combined therapy effects at mixed (PVY, PVS, PLRV, PVX) and simple viral infections in potato. However, I.A. Nasir at el. [37] report on the recovery of potato plants with mixed infection from potato viruses $S, M, X$ and note the complete absence of recovery effect from PVY and PLRV.

We did not find any significant differences in the recovery of plants infected by different viruses (see Fig. 2, Table 3). In total, among 91 clones PLRV was eliminated in $72.7 \%$, PVY in $71.4 \%$, PVM in $63.9 \%$, and PVS in $57.4 \%$ of the micro-plants. At that, the differences between the studied potato species for elimination of each virus species were also not significant $(\mathrm{p}>0.05)$.

3. Frequency of potato micro-plants $(\%)$ free from viruses after application of proposed complex thermo-chemotherapy $(n=91, X \pm x)$

\begin{tabular}{l|l|c|c|c|c}
\hline \multicolumn{1}{c|}{ Virus } & $\begin{array}{l}\text { Solanum } \\
\text { phureja }\end{array}$ & S. stenotomum & $\begin{array}{l}\text { S. tuberosum } \\
\text { ssp. andigenum }\end{array}$ & $\begin{array}{l}\text { S. tuberosum } \\
\text { ssp. tuberosum }\end{array}$ & Total \\
\hline PVX & $0^{\mathrm{B}}$ & $0^{\mathrm{B}}$ & $50.0 \pm 50.0^{\mathrm{a}, \mathrm{b}, \mathrm{c}}$ & $100.0 \pm 0.0^{\mathrm{a}}$ & $80.0 \pm 20.0^{\mathrm{a}, \mathrm{b}}$ \\
PVY & $33.3 \pm 21.1^{\mathrm{b}, \mathrm{c}}$ & $50.0 \pm 18.9^{\mathrm{b}}$ & $93.3 \pm 6.7^{\mathrm{a}}$ & $75.0 \pm 9.9^{\mathrm{a}, \mathrm{b}}$ & $71.4 \pm 6.5^{\mathrm{a}, \mathrm{b}}$ \\
PVS & $77.8 \pm 14.7^{\mathrm{a}}, \mathrm{b}$ & $23.1 \pm 12.2^{\mathrm{c}}$ & $57.1 \pm 13.7^{\mathrm{b}}$ & $81.8 \pm 12.2^{\mathrm{a}, \mathrm{b}}$ & $57.4 \pm 7.3^{\mathrm{b}}$ \\
PVM & $63.6 \pm 15.2^{\mathrm{a}}, \mathrm{b}$ & $66.7 \pm 9.8^{\mathrm{a}, \mathrm{b}}$ & $61.1 \pm 11.8^{\mathrm{b}}$ & $63.2 \pm 11.4^{\mathrm{a}, \mathrm{b}}$ & $63.9 \pm 5.7^{\mathrm{a}, \mathrm{b}}$ \\
PLRV & $66.7 \pm 33.3^{\mathrm{a}}, \mathrm{b}$ & $100.0 \pm 0.0^{\mathrm{a}}$ & $77.8 \pm 14.7^{\mathrm{a}, \mathrm{b}}$ & $66.7 \pm 11.4^{\mathrm{b}}$ & $72.7 \pm 7.9^{\mathrm{a}, \mathrm{b}}$
\end{tabular}

П р и м е ч н и е. PVX, PVY, PVS, PVM - potato viruses X, Y, S and M, respectively, PLRV - potato leafroll virus. Values marked with the same letters are not significantly different $(\mathrm{p}<0.05)$.

Our results on elimination of PVY, PVM and PLRV using the combined thermo-chemotherapy are in line the literature data [9-11, 27, 38, 42] (see Table 1). The proportion of PVS-free plants in our study was $57.4 \%$, while in other studies [11, 38] almost complete elimination (more than $90 \%$ ) was reported. Note that in these studies, the authors used ELISA [11, 38], which is less sensitive than the RT-PCR analysis used by us. As per literature data, in most studies single potato samples [16, 17] or a very small number of samples [38, 42], mostly with simple viral infections [17], were subjected to complex therapy.

So, we proposed a modified protocol for a complex thermo-chemotherapy of potato micro-plants under RT-PCR control of virus infection. This protocol resulted in a comparable eliminating effect for five the most harmful viruses in a genetically diverse 85 samples (91 clones) of three cultivated potato species, which indicates the prospect of further use of the modified thermochemotherapy method in the centers of plant genetic resources. The proposed modification differs from the known protocols by simultaneous exposure to elevated temperature and ribavirin, and also by shorter processing cycle.

\section{REFERENCES}

1. Polevaya kollektsiya kartofelya VIR [VIR Potato field collection]. Available http://vir.nw.ru/otd_r.htm\#tuber. Accessed Ocober 4, 2016 (in Russ.).

2. J e ffries C.J. Potato. FAO/IPGRI technical guidelines for the safe movement of germplasm. FAO and IPGRI, Rome, 1998.

3. Virus and virus-like diseases of potatoes and production of seed potatoes. G. Loenbenstein, P.H. Berger, A.A. Brunt, R.H. Lawson (eds.). Springer Netherlands, The Netherlands, 2001 (doi: 10.1007/978-94-007-0842-6).

4. Vlasov Yu.I., La ri na E.I., Truskinov E.V. Sel'skokhozyaistvennaya fitovirusologiya [Agricultural phytovirology]. St. Petersburg, 2016 (in Russ.).

5. Anisimov B.V., B elov G.L., Varitsev Yu.A., Elanski S.N., Zhuromski i G.K., Z avriev S.K., Z e iruk V.N., Ivanyuk V.G., Kuznetsova M.A., Plyakhnevich M.P., P shechenkov K.A., S i makov E.A., Sklyarova N.P., U sk ov A.I., Y a s hin a I.M. Zashchita kartofelya ot boleznei, vreditelei $i$ sornyakov [Poteto protection from diseases, pests and weeds]. Moscow, 2009 (in Russ.).

6. M o re 1 G.T., M a rt i n C. Guerison de dahlias atteints dune maladie a virus. Comptes Rendus de l'Académie des Sciences, Ser. III, 1952, 235: 1324-1325.

7. Truskinov E.V. Sel'skokhozyaistvennaya biologiya [Agricultural Biology], 1976, 11(2): 250- 
255 (in Russ.).

8. Wang Q.C., Li u Y., Xi e Y.H., Y o u M. Cryotherapy of potato shoot tips for efficient elimination of Potato leaf roll virus (PLRV) and Potato virus Y (PVY). Potato Res., 2006, 49(2): 119-129 (doi: 10.1007/s11540-006-9011-4).

9. Băd ă $\breve{a}$ u C.L., C h i r u N. Effect of some therapies on potato plantlets infected with potato virus X (PVX). Journal of EcoAgriTourism, 2014, 10(1/28): 11-17.

10. Mahmoud S.Y.M., Hosseny M.H., Abdel-Ghaffar M.H. Evaluation of some therapies to eliminate Potato Y potivirus from potato plants. Int. J. Virol., 2009, 5(2): 64-76 (doi: 10.3923/ijv.2009.64.76).

11. Griffith s H.M., S la ck S.A., D odd s J.H. Effect of chemical and heat therapy on virus concentration in in vitro plantlets. Can. J. Bot., 1990, 68: 1515-1521.

12. Cass e $11 \mathrm{~s} \mathrm{A.C.,} \mathrm{L} \mathrm{o} \mathrm{ng} \mathrm{R.D.} \mathrm{The} \mathrm{elimination} \mathrm{of} \mathrm{potato} \mathrm{viruses} \mathrm{X}, \mathrm{Y}, \mathrm{S}$ and $\mathrm{M}$ in meristem and explant cultures of potato in the presence of Virazole. Potato Res., 1982, 25: 165-173.

13. Fac cioli G., Colalong o M.C. Eradication of Potato virus Y and Potato leafroll virus by chemotherapy of infected potato stem cuttings. Phytopathol. Mediterr., 2002, 41: 76-78.

14. Truskinov E.V., Rog o zi n a E.V. Fiziologiya rastenii, 1997, 43: 432-439 (in Russ.).

15. A t ab e kov I.G., T a l'y a n ski i M.E. V sbornike: Dostizheniya sel'skokhozyaistvennoi nauki [In: Progress in agricultural science]. Moscow, 1987: 121-136 (in Russ.).

16. Nascimento L.C., Pio-Ribeiro G., Willadino L., And rade G.P. Stock indexing and potato virus $\mathrm{Y}$ elimination from potato plants cultivated in vitro. Scientia Agricola, 2003, 60(3): 525-530 (doi: 10.1590/S0103-90162003000300017).

17. Dhital S.P., S a kha B.M., Li m H.T. Utilization of shoot cuttings for elimination of PLRV and PVY by thermotherapy and chemotherapy from potato (Solanum tuberosum L.). Nepal Journal of Science and Technology, 2006, 7: 1-6.

18. Techniques in plant virology. Section 4.2. Virus eradication: tissue culture of meristems, thermotherapy, and chemotherapy. L. Salazar, U. Jayasinghe (eds.). International Potato Center, Lima, Peru, 1999.

19. Panta A., Tay D., Go mez R., Z e a B., Rojas E., S i mon R., Roca W. Status and impact of the in vitro conservation of root and tubers at the International Potato Centre (CIP). Proc. $15^{\text {th }}$ Triennial Symposium of the International Society for Tropical Root Crops. Lima, Peru, 2009: 15-24.

20. Operational Genebank manual of IPK. Gatersleben, 2011.

21. Li z a r raga R., P a n t a A., J a y a s i $\mathrm{g}$ h e U., D o d d s J. Tissue culture for elimination of pathogens. CIP Research Guide 3. International Potato Center, Lima, Peru, 1991.

22. Jianming B., Xiaoling C., Xinxiong L., Huachun G., Xia X., Zhie Z. Can cryopreservation eliminate the Potato virus X (PVX) and Potato spindle tuber viroid (PSTVd)? Bioscience Methods, 2012, 3(5): 34-40 (doi: 10.5376/bm.2012.03.0005).

23. F a c cioli G. Control of potato viruses using meristem and stem-cutting cultures, thermotherapy and chemotherapy. In: Virus and virus-like diseases of potatoes and production of seedpotatoes. G. Loebenstein, P.H. Berger, A.A Brunt, R.H. Lawson (eds.). Springer Netherlands, 2001: 365-390 (doi: 10.1007/978-94-007-0842-6_28).

24. Heldak J. Detection of potato virus $\mathrm{S}$ by RT-PCR in potato regenerants derived from in vitro heat-treated shoot tips. Acta fytotechnica et zootechnica, 2001, 4: 275-277.

25. Kl e i n R.E., Livi ng s t o n C.H. Eradication of potato viruses X and S from potato shoot-tip cultures with ribavirin. Phytopathology, 1983, 73(7): 1049-1050 (doi: 10.1094/Phyto-73-1049).

26. Yang L., Ni e B., Li u J., S o ng B. A reexamination of the effectiveness of ribavirin on eradication of viruses in potato plantlets in vitro using ELISA and quantitative RT-PCR. Am. J. Potato Res., 2014, 91(3): 304-311 (doi: 10.1007/s12230-013-9350-z).

27. S a n c he z G.E., S la ck S.A., D odds J.H. Response of selected Solanum species to virus eradication therapy. Am. Potato J., 1991, 68: 299-315 (doi: 10.1007/BF02853668).

28. Hawkes J.G. The potato. Evolution, biodiversity, genetic resources. Belhaven Press, London, 1990.

29. B u k a s ov S.M. Trudy po prikladnoi botanike, genetike i selektsii (Leningrad), 1978, 62(1): 335 (in Russ.).

30. Dunaeva S.E., Pendinen G.I., Antonova O.Yu., Shvachko N.A., Volkova N.N., G a vrile n k o T.A. Sokhranenie vegetativno razmnozhaemykh kul'tur $v$ in vitro $i$ kriokollektsiyakh /Pod redaktsiei T.A. Gavrilenko [Preservation of vegetatively propagated crops in vitro and in cryo collections. T.A. Gavrilenko (ed.)]. St. Petersburg, 2011 (in Russ.).

31. Nabor "Vydelenie total'noi RNK na magnitnykh chastitsakh, pokrytykh $\mathrm{SiO}_{2}$ " [Kit for total RNA isolation on magnetic particles coated with $\mathrm{SiO}_{2}$ ]. Aailable http://www.sileks.com/ru/production.php?folder=189. Accessed September 25, 2016 (in Russ.).

32. Nabor «Sintez pervoi tsepi kDNK (rendom)» firmy Sileks [Kit for first cDNA shain random synthesis. Sileks company]. Available http://www.sileks.com/ru/production.php?folder=65. Accessed September 25, 2016 (in Russ.).

33. S i n g h R.P. Development of the molecular methods for potato virus and viroid detection and prevention. Genome, 1999, 42: 592-604. 
34. Xu H., D'Aubi n J., Ni e J. Genomic variability in Potato virus $\mathrm{M}$ and the development of RT-PCR and RFLP procedures for the detection of this virus in seed potatoes. Virol. J., 2010, 7: 25 (doi: 10.1186/1743-422X-7-25).

35. B o st a n H., P e k e r P.K. The feasibility of tetraplex RT-PCR in the determination of PVS, PLRV, PVX and PVY from dormant potato tubers. Afr. J. Biotechnol., 2009, 8(17): 4043-4047.

36. $\mathrm{N}$ i cot N., H a u s m a $\mathrm{n}$ J.-F., H of $\mathrm{fm}$ a $\mathrm{n}$ L., E v e r s D. Housekeeping gene selection for real-time RT-PCR normalization in potato during biotic and abiotic stress. J. Exp. Bot., 2005, 56(421): 2907-2914 (doi: 10.1093/jxb/eri285).

37. N a s i r I.A., T ab a s u m B., L a t if Z., J aved M.A., Ha ide r M.S., J aved M.A., Hus nain T. Strategies to control potato virus y under in vitro conditions. Pak. J. Phytopathol., 2010, 22(1): 63-70.

38. Z a p a a C., Mille r J.C., Jr., S mith R.H. An in vitro procedure to eradicate potato viruses $\mathrm{X}, \mathrm{Y}$, and $\mathrm{S}$ from Russet Norkotah and two of its strains. In Vitro Cellular \& Developmental Biology - Plant, 1995, 31(3): 153-159 (doi: 10.1007/BF02632012).

39. M o r o z o v a Z.R. Biologicheskie nauki, 1992, 338(2): 128-134 (in Russ.).

40. L e o n o v N.S., S a lg a n i N.I. Sibirskii vestnik sel'skokhozyaistvennoi nauki, 1991, 5: $25-$ 28 (in Russ.).

41. Lopez-Delgado H., Mora-Herrera M.E., Zavaleta-Mancera H.A., Cade n a - H in ojos a M., S c ott I.M. Salicylic acid enhances heat tolerance and potato virus X (PVX) elimination during thermotherapy of potato microplants. Am. J. Potato Res., 2004, 81(3): 171-176 (doi: 10.1007/BF02871746).

42. Pa et C.N., Z a mor a A.B. Efficacy of thermotherapy and group culture of isolated potato meristems for the elimination of single and mixed infections of Potato Virus Y, Potato Virus $\mathrm{S}$ and Potato Leaf Roll Virus. Philipp. J. Crop. Sci., 1990, 15(2): 113-118. 